\title{
Demystifying the Mystery That Surrounds the Comprehension of Poetry via Song Therapy: Our Experience
}

\author{
Asso. Prof Chinyere Maduabuchi \\ Dept. of Arts and Social Science Education, Faculty of Education \\ Ebonyi State University, Abakaliki, Ebonyi State, Nigeria \\ ettachimlo@yahoo.com
}

Dr Patricia Eziamak Ezenandu

Federal College of Education

Osele, Abeokuta, Ogun State,Nigeria

Tricia.amakaeze@gmail.com

\begin{abstract}
The study, 'Demystifying the mystery that surrounds the comprehension of poetry through song therapy: Our experience', adopted a pretest, posttest quasi experimental research design to measure students' comprehension in English poetry using song therapy. 284 students from selected intact classes in Junior Secondary School II and Senior Secondary School II were used in both experimental and control groups. The experimental groups were taught poetry with songs, while the control groups used the conventional method. The study used 104 male students for the experimental groups, 31 male students for the control group, 107 and 42 females for the experimental and control groups respectively. Means and standard deviation were used for the research questions, while Analysis of Covariance (ANCOVA) was used for the hypotheses at 0.05 level of significance. The findings of the study indicate a significant difference in the mean achievement scores of students taught poetry with song therapy and those taught with the conventional approach.
\end{abstract}

\section{INTRODUCTION}

Literature in English is one of the subjects of study at the senior secondary schools in Nigeria, but at the junior secondary level, it is integrated within the English language curriculum. Out of the three genres of literature in English offered in schools, poetry is often regarded as being abstract in nature. The researchers taught Literature- in -English at the junior and senior secondary schools and had remarkable experiences that prompted this topic.

Poetry as a genre plays a very significant role in our lives because it awakens our senses, connects us with ourselves and others and leads us to think in synthesizing ways, as required by its use of the language of metaphor (Zwicky, 2000; Hoogland, 2011). Poetry is seen as an abstract course that poses a lot of difficulties to second language learners. This is because most students often get disenchanted, whenever they are in poetry classes and our ugly experiences as poetry teachers suggested that students seem not to like poetry. This is reiterated in the consistent low grades students obtain in poetry in most of the external examinations. This was further buttressed in the West African Examination Council (WAEC) Chief Examiner's Report (2013:40) on the poetry aspect of literature in - English thus:

Candidates were narrating poems, when they should be discussing, analyzing, examining or explaining specific notions, occurrences, opinion, and assertions etc. Candidates must note that narration and discussion are not the same... The blunders (unpardonable mistakes) that abound in candidates' answers often confirm unfamiliarity with the poems.

This implies that most candidates, who sat for the WAEC examination of 2013, had difficulty giving correct answers to questions because they were not familiar with some of the poems they were examined on. Suffice it to mean that most of the students may have studied those poems without internalization hence, when questions were asked in those poems they were not able to remember issues that pertain to them. In other words, the students were never attracted to the poems in the first place. Poetry has a unique kind of attraction that is embedded in its conciseness, brevity and the power to convey so much in a limited space (Hijazi\& Al-natour, 2012). 
Poetry as a genre of literature is frequently neglected and poorly taught. This is without cognizance to the tremendous benefit that literature offers to both teachers and students in particular. We observed that most teachers of Literature- in -English often avoid teaching poetry due to its unique nature. Consequently they use the time allotted for poetry to teach prose or drama instead. This is informed by the fact that most teachers are ignorant of some meta-cognitive instructional strategies that could be adopted to make literature or poetry classrooms learner-centered spaces.

Poetry has a central place in the secondary English curriculum because it helps students in the acquisition and use of words. Ofsted (2006:6) describes poetry thus:

Poetry matters because it is a central example of the use human beings make of words to explore and understand. Like other forms of writing we value, it lends shape and meaning to our experiences and helps us to move confidently in the world we know then to step beyond it.

The argument here is that poetry should be given adequate time in the English language studies because of the quality of language it explores and the imaginative experience it offers learners.

Fakeye and Temitayo (2013) provide greater insight on the importance of literature as a study that makes for the development of the cognitive, affective and psychomotor domains of an individual. It develops the cognitive domains of the individual as it develops the capacity for discrimination, judgment and decision. In affective domain, it shapes an individual's taste, develops his/her sympathy and empathy and the expression of feelings and emotions. In the psychomotor domain, it provides avenue for dramatization and active participation by the individuals involved (Simpson, 2004).

Poetry impacts greatly on feelings and the senses as Borsna cited in Fakeye and Temitayo (2013:51) observes thus:

The words in poetry are carefully chosen in a way to make them sound musical and meaningful. Poetry is written in verse and can only be realized when it is recited or sung. This is because every good poem is first and foremost meant to be sung. Poetry is not easily understood when reading. Research has shown that among the three genres of literature, poetry seems the most difficult. This is because of its ambiguity, obscurity, and unfamiliarly nature. As a subject that features prominently in the school curriculum, the failure rate in it at the school certificate level in spite of all the good efforts of researches, is a phenomenon that is giving students, teachers and school authorities a big concern.

Irrespective of the beauty of poetry, an abysmal record of failure has continued to trail it at the school certificate examinations. One begins to wonder why this situation should persist when poetry has a lot of benefits attached to it. We remember vividly that during the period we were teaching poetry in both the Junior Secondary School (JSS) and Senior Secondary School II, most of our students were completely uninvolved and felt that it does not arouse their curiosity as the other genres of literature do. The above submission from Fakeye and Temitayo (2013) indicates that an average reader can identify the fact that poetry is an unsung songs. Thus studying poetry under an incompetent teacher poses great difficulties to second language learners. Pedagogical factors have often been blamed with respect to students' attitude to and performance in poetry. Most of the poetry teachers in schools are not well informed on the right pedagogy that would facilitate students' comprehension of poetry and enhance their performance in poetry related examinations.

The conventional approach that teachers use in the teaching of poetry in secondary schools in Nigeria make poetry a boring and unconnected subject of study. Such conventional methods are obvious departure from the child-centred strategies that are required for lifelong learning in this $21^{\text {st }}$ century. According to Lo and $\mathrm{Li}$ (1998), song is an adequate therapy that is able to change the monotonous mood often associated with conventional classrooms. The amusing and relaxing mood often brought by songs to the class eases the effects of certain emotional cases such as boredom, anxiety, lack of self-confidence and the feeling of being threatened. In addition to that, song has a positive influence on the learning process by stimulating students emotionally (Saricoban, 2000).

In each of the poetry lessons, where we applied song therapy, we discovered that our students were encouraged to be actively involved in the learning process by making use of their musical knowledge (Sahin, 2008). It had been argued that when students listen to and memorize songs in the class, the lyrics are embedded in their long-term memory. Neurological researches have shown that musical and lingual processes occur in the same section of the brain and that there are significant similarities 
between musical and lingual syntax (Maess \& Koelsch, 2001). Earlier observations by Falioni (1993) indicated that students use songs in the classroom for enjoyment, not for learning. Students have often trivialized the core message of poetry as mere admonitory statements from the poets. He however concludes that using songs while learning can enhance the process of learning, if used with much more care and caution on the side of the teachers, because students need to understand that the therapy is meant for enhancement of comprehension and not as a mere entertainment. Wiliot as cited in Hijazi \& Alnatour (2012) remarks that, song when used as a therapy for fixing comprehension breakdown "improves pronunciation memory through organizational framework, linear time order, expectation, repetition, residual learning, lowering affective barriers, and anticipation of patterns, resolution cues, gestalt cues or schema and anchors for memory" (p. 297)

In this study, efforts have been made to identify how the song therapy would be effectively implemented in English as a second language (ESL) literature classroom during poetry lesson. It is believed that a competent teacher of Literature -in- English should be able to use song in the teaching of poetry to facilitate comprehension and appreciation of the poems. Comprehension in this context is the ability of the learners to construct an independent meaning from the poems read. This means that metacognitively, the student should be made to have knowledge, awareness, and control over any poem they encounter. It suggests mastery, and in this respect mastering the details of each poem studied. This includes the figurative languages of the poems, imageries, symbols, rhyming scheme, theme, plot and other essential ingredients embedded in a poem. It means the stage, where a learner is at liberty with the details of the poem in a fun-like activity like song. Comprehension remains the hallmark of every reading exercise and it could only be established, when a student has taken active role in the learning exercise such that he/she is able to internalize the details of such exercise and subsequently attempts the construction of independent meanings.

Comprehension is seen as a critical thinking process because it is a critical thinking act (Aloaili 2005 d). Schema theory posits that the understanding and interpretation of the text are relative, meaning that definitive conclusions cannot be reached, instead readers seek to arrive at a coherent and consistent understanding of the text being read (Aloqaili, 2012). Therefore, Lewis (1991: 421) buttresses the concept of comprehension in these words:

There is no absolute meaning on the page to be interpreted the same by all that is, there is no correct comprehension. The goal of reading extended text is to arrive at a coherent representation of the text. This goal is achievement by readers, weighing and comparing data from their schemata, the text and the context in which the act occurs.

To enhance readers' ability to achieve the comprehension of poetry, the reader uses his/her metacognitive knowledge and applies metacognitive strategies in a playful, but purposeful way throughout the critical thinking process (French \& Rhoder, 1992).

For the purpose of this study, the researchers resort to the poems in the scheme of work of the intended target audience. The curriculum for the target classes already had poems that were designed for students' comprehension for the term. From the bank of these poems, the researchers selected the poems that were used for the experiment. In the selection of poems, strict adherence was paid to these rules:

- We chose poems that were already preselected for students' use within the period of their study.

- We selected poems that are not gender biased. To ensure maximum cooperation of both male and female students, we selected poems that have general themes without any form of segregation on gender.

- All the poems selected had no embarrassing part (s) that would be difficult to explain to the students.

- Poems that are within the comprehension ability of the learners. In other words, poems that are commensurate to the age of the target audience.

Based on these criteria, the researchers set out to experiment their previous experiences with different sets of students in a different State entirely. Students from both rural and urban areas were also selected to be part of the study. The reason was basically to ascertain, if the song therapy would yield the same result, when used with students in both the rural and urban areas. Music is often referred to 
as a soothing balm to the soul which does not exclude people living in rural areas. In fact, experience has shown that the students at both the rural and urban areas would perform favourably well in examinations, if they are given equal degree of comfort in learning and are both exposed to childcentred instructional strategies.

\section{SignifiCANCE OF THE STUdY}

It is naturally believed that poetry is the hardest and most difficult genre in literature-in-English. This is informed by its peculiar structure (Pike 2000). Most literature-in-English teachers do not teach the poetry aspect of literature, because of the mystery of incomprehension and difficulty that surround it. Our decision and choice of song therapy was informed by the fact that poetry, like songs is usually written in stanzas. Poems are unsung songs and if students perform poorly in it, it is simply because they have neither realized the entertaining quality of poem nor the fact that the songs in their hymn books, which they often take delight in chanting, are also poems. Thus we need to find meaningful ways to engage students with poetry in other to broaden their understanding of life(Hughes 2006). Songs are some of those meaningful ways through which the mystery surrounding poetry will be demystified. Poetry teachers and students will benefit immensely from this research because it act as an open opener to all.

\section{Statement of the Problem}

Song and music in classrooms are often regarded as means of entertainment and recreation only. Based on this, students often trivialize the importance of song as a pedagogical tool. The incessant boredom, disenchantment, passivity and abstractness that characterize poetry lessons are made more manifest in students' poor performance in poetry aspect of the literature- in- English examinations in Nigeria. This study stems from our personal experiences as poetry teachers in secondary schools some years back. We had the greatest challenge of our time trying to fix comprehension breakdown in almost every poetry lesson we had. Thus, when we complained to students of their nonchalant attitude to poetry lesson, they suggested that we should rather concentrate more on other genres of literature such as drama and prose than waste time trying to make them appreciate poetry. This was a sincere demand arising from their obvious disconnection with the poetry lessons. Therefore, we met and brainstormed on the best way to fix the comprehension breakdown and we finally resorted to the use of song therapy. This study is a replay of the experiences of the researchers in another empirically verified study.

\section{Purpose of the Study}

The purpose of this study is to investigate the potency of song therapy in demystifying the mystery that usually surrounds the comprehension of poetry. Specifically, this study sought to:

- Investigate the effect of song therapy on the mean achievement scores of students in poetry.

- Establish the mean achievement scores of urban and rural school students that were taught poetry using the song therapy.

- Find out the mean achievement scores of junior and senior secondary school students that were taught poetry using the song therapy

- Ascertain the mean achievement scores of male and female students that were taught poetry using the song therapy

\section{RESEARCH QUESTIONS}

1. What is the effect of song therapy on the mean achievement scores of students in poetry?

2. What is the mean achievement scores of urban and rural school students that were taught poetry using the song therapy?

3. What is the mean achievement scores of junior and senior secondary school students that were taught poetry using the song therapy?

4. What is the mean achievement scores of male and female students that were taught poetry using the song therapy? 


\section{HYPOTHESES}

HO$_{1}$ : There is no significant difference in the mean achievement scores of students taught poetry using the song therapy and those taught with the conventional approach.

$\mathbf{H O}_{2}$ : There is no significant difference in the mean achievement scores of junior and senior secondary students taught poetry using the song therapy

$\mathbf{H O}_{3}$ : There is no significant difference in the mean achievement scores of urban and rural secondary students taught poetry using the song therapy

$\mathbf{H O}_{4}$ : There is no significant difference in the mean achievement scores of male and female secondary school students taught poetry using the song therapy.

\section{MeThodology}

The population of the study consists of all the JSS II and SSSII students in Abakaliki Education Zone of Ebonyi State. A multi-stage sampling technique was used in selecting a sample of 284 Junior and senior secondary school students from Abakaliki Education Zone. Six schools were randomly selected from this zone using the ballot system and purposive sampling technique was applied in the selection of the intact classes from each of the selected schools in both the urban and rural areas. Two JSSII treatment classes and one control were selected from urban and rural schools respectively. The same process was also used in the selection of the SSII classes for the study. The students in each of the classes selected were used without randomization because we needed heterogeneous intact classes of male and female students. We had 120 male and female students for the junior experimental classes, 91 male and female students for the senior experimental classes and 73 students from the two control groups. Making a total of 284 students used as sample for the study. The study adopted a pretest posttest nonequivalence group quasi experimental research design. Six intact classes from urban and rural schools were used in the experiment. Two strategies were adopted for this study: The first strategy was song therapy, while the second strategy was conventional strategy. A test instrument made up of short essay was designed based on the scheme of work of the JSS II and SSSII students in poetry and used for data collection (See Appendix 1). A test retest procedure was applied to a sample of 32 students selected from another education zone not used for study, for the purpose of establishing the internal consistency of the test instrument. A period of two weeks was used for the exercise. The reliability of the test was calculated and 0.82 was obtained using Pearson Product Moment correlation coefficient.

Six groups of students were used for the study. They are:

- Experimental Group I: This consists of the JSS II students in the rural school.

- Experimental Group II: This is made up of the JSSII students in the urban school

- Experimental Group III: SSS II students in the rural school

- Experimental Group IV: SSS II students from the school in the urban area

- Control Group I: JSS II students.

- Control Group II: SSSII students.

The six groups received 8 weeks of instruction on poetry using song therapy and conventional strategies respectively. Meanwhile, the participants in the six groups were administered the pretest prior to the 8 weeks of treatment. At the end of the treatment, they were also subjected to the posttest. The research assistants, who participated in the study, were also subjected to two weeks of training before the commencement of the treatment. The entire study lasted for 12 weeks.

The following steps were used in the administration of the treatment

\subsection{Step I: Mastery of the Song Therapy in a Poetry Class}

The songs used in a poetry class must be simple in terms of the rhythm and lyrics and to utilize songs in the poetry class, a certain amount of attention is required. Therefore, the researchers took into consideration the rhythm of some of the popular Christian songs "Stand up, Stand up for Jesus", "Fade, fade each earthly joy" and any other conventional tune that suits the lyrics of the chosen 
poem(s). The teacher of poetry, who wishes to use song therapy, must be innovative and ingenious to be able to carry the students along. When a particular tune failed to match the words of the selected poem, the teachers kept the class going by realigning the poem to suit any particular tune that might be composed spontaneously. This was exactly the step taken by the researchers in this study.

\subsection{Step II: Steps to Adhere to in the Use of Song Therapy}

Whenever a poetry teacher wishes to use song therapy in any classroom environment, such a teacher must ensure that:

- The classroom is conducive enough. Conduciveness implies a well-ventilated classroom with spacious aisle, where the teacher is able to move around and encourage students, who sit at the far ends of the classrooms to participate.

- The interest of the students are taken into cognizance. This is predicated on the age of the students, number in class and the general appeal of the chosen rhythm.

- Teacher factor also played an important role. The teacher has to be interested in music in the first place; his age should also be considered because the older generation of teachers appears see song therapy as an unnecessary distraction and undue waste of instruction time. This is because of their conservative inclination to traditional teaching strategies. Hence, the researchers considered age as an important factor in the selection of research assistants.

- The lesson hours are adequate and appropriate. This therapy was used during double periods because the aim was to give the teacher enormous time to sing the poem repeatedly before delving into the literary appreciation/analysis of the poem.

\subsection{Step III: Interactive / Demonstration Sessions in Poetry Classes using Song Therapy}

Model demonstration with regards to the reading/recitation of the poems is the first approach to this therapy, followed by singing the selected poems by the teacher. The social learning theory highlights the importance of learning in a social context, because it is known to enhance comprehension. Therefore, during treatment, interactive sessions and demonstrations were built into the lesson. Every student was given opportunity to interact freely with other members of the class. At this step students were made to sing the poems repeatedly after the teacher, following the adopted tune; form small groups of 8-10 students, where those, who had mastered the tune of the song act as models for their peers. This was followed by the literary appreciation of the poem both in small groups and whole class situation.

\subsection{Step IV: Ways of Adhering to an Already Known Tune in Every Poetry Class}

This is where the ingenuity of the poetry teacher is required. The poetry teacher adapts the poem to the chosen conventional tune and models the tune to the students. In this regard, the researchers made use of the popular conventional tunes of "Stand up, Stand up for Jesus" and "Fade, Fade each earthly Joy". If a teacher finds out that the words of a poem are longer or shorter to adapt to an already known tune, the teacher should quickly switch to another tune. This approach calls for adequate preparation and practice by the teacher prior to the lesson.

\subsection{Step V: Ways to Ensure Maximum Students' Participation}

During the use of song therapy, the students were divided into smaller groups to achieve a deeper comprehension of the poem. The teacher produces the model tune and synchronizes the tune with the poems in a whole class. After that, the song continues until the teacher assigns them to their groups, where they consolidate on the practice and go into the appreciation of the poems. At the end of the small group meetings, the teacher reconvenes the students for a whole class discussion of the poems and further literary analysis of the poems.

\subsection{Step VI: Modeling Pattern Required of any Teacher Who Uses Song Therapy in a Poetry Class}

In the study, we took strict adherence in training the research assistants into the right modeling pattern required of them during the experiment. This modeling pattern includes the following:

- Creativity

- Spontaneity 
- Availability

- Relative good voice

- Movement and

- Flexibility

The research questions were answered using inferential statistics of mean and standard deviation, while the hypotheses were analyzed with the Analysis of Covariance (ANCOVA) at 0.05 level of significance.

\section{RESUlts}

\subsection{Research Question 1}

What is the effect of song therapy on the mean achievement scores of students in poetry?

Table1. Mean achievement scores of secondary school students taught poetry using the song therapy and those taught with the conventional approach.

\begin{tabular}{|l|l|l|l|}
\hline Methods & Mean & SD & N \\
\hline Song Therapy & 56.55 & 9.7 & 211 \\
\hline Conventional Method & 33.85 & 10.81 & 73 \\
\hline
\end{tabular}

The result in Table 1 shows that the experimental groups had a mean of 56.55 and a standard deviation (SD) of 9.7, while the control groups taught with conventional strategy had a mean of 33.85 and a standard deviation of 10.81. This is an indication that the song therapy had a positive effect on students exposed to the treatment.

\subsection{Research Question 2}

What is the mean achievement scores of urban and rural school students that were taught poetry using the song therapy?

Table2. Mean achievement scores of urban and rural secondary school students taught poetry using the song therapy.

\begin{tabular}{|l|l|l|l|}
\hline School Location & Mean & SD & N \\
\hline Urban & 56.82 & 9.73 & 123 \\
\hline Rural & 56.18 & 9.93 & 88 \\
\hline
\end{tabular}

Evidence from the result on the mean achievement scores of urban and rural students taught poetry using song therapy, shows that the urban students obtained a mean of 56.82 and a SD of 9.73, while the students in the rural schools had a mean of 56.18 and SD of 9.93. The closeness in the results proved that both the students in the rural and urban areas had better performance through exposure to the song therapy.

\subsection{Research Question 3}

What is the mean achievement scores of Junior and Senior secondary school students that were taught poetry using the song therapy?

Table3. Mean achievement scores of junior and senior secondary school students taught poetry using the song therapy

\begin{tabular}{|l|l|l|l|}
\hline Class categories & Mean & SD & N \\
\hline Junior Secondary & 56.81 & 9.51 & 120 \\
\hline Senior Secondary & 56.22 & 10.21 & 91 \\
\hline
\end{tabular}

The result on table 3 shows that JSS II students, who were taught poetry with song therapy had a mean score of 56.81 and a SD of 9.51, while the SSII students taught with the song therapy had a mean score of 56.22 and a SD of 10.2 showing that both performed significantly well with the song therapy.

\subsection{Research Question 4}

What is the mean achievement scores of male and female students that were taught poetry using the song therapy? 
Table4. Mean achievement scores of male and female secondary school students taught poetry using the song therapy

\begin{tabular}{|l|l|l|l|}
\hline Gender Categories & Mean & SD & N \\
\hline Male & 56.74 & 9.24 & 104 \\
\hline Female & 56.37 & 10.35 & 107 \\
\hline
\end{tabular}

From the result presented in Table 4, we can deduce that the male students obtained a mean scores of 56.74 and SD of 9.24, while the female students had a mean achievement score of 56.37 and a SD of 10.35. The nearness in the mean scores shows that both the male and female students did well with the therapy.

\subsection{Hypothesis}

HO : There is no significant difference in the mean achievement scores of students taught poetry using the song therapy and those taught with the conventional approach

Table5. Analysis of Co-variance for students overall poetry achievement scores by teaching method

\begin{tabular}{|l|l|l|l|l|l|}
\hline Sources of Variation & Sum of Squares & DF & Mean Square & F.cal & F.cv \\
\hline Covariate & 35845.170 & 1 & 35845.170 & 904.730 & \\
\hline Main Effect (Method) & 8625.210 & 1 & 8625.210 & 217.700 & 3.89 \\
\hline Explained & 45517.171 & 5 & 9103.434 & 229.770 & \\
\hline Residual & 11014.294 & 278 & 39.620 & & \\
\hline Total & 56531.465 & 283 & 199.758 & & \\
\hline
\end{tabular}

Result of data analysis summarized in Table 5 reveals that the calculated F.value is 217.700 , while the critical value at alpha level of 0.05 is 3.89 . The decision rule is to reject the null hypothesis when the calculated value exceeds the critical value. Based on the decision rule, the null hypothesis was rejected and the study concludes that there is a significant difference in the mean achievement scores of students taught poetry using the song therapy and those taught with the conventional strategy.

$\mathbf{H O}_{2}$ : There is no significant difference in the mean achievement scores of junior and senior secondary school students taught poetry using the song therapy.

Table6. Analysis of Co-variance for students' poetry achievement scores by class category

\begin{tabular}{|l|l|l|l|l|l|}
\hline Sources of Variation & Sum of Squares & DF & Mean Square & F.cal & F.cv \\
\hline Covariate & 9962.301 & 1 & 9962.301 & 216.944 & \\
\hline Main Effect (Class) & 229.418 & 1 & 229.418 & 4.996 & 3.89 \\
\hline Explained & 10880.071 & 8 & 1360.009 & 29.616 & \\
\hline Residual & 9276.052 & 202 & 45.921 & & \\
\hline Total & 20156.123 & 210 & 95.982 & & \\
\hline
\end{tabular}

Summary of data analysis in Table 6 reveals that the calculated F.value is 4.996, while the critical F.value is 3.89. Since the calculated value is greater than the critical value at $95 \%$ confidence level, the null hypothesis is rejected, indicating that there is a significant difference in the mean achievement scores of junior and senior secondary school students exposed to the treatment.

$\mathbf{H O}_{3}$ : There is no significant difference in the mean achievement scores of urban and rural secondary school students taught poetry using the song therapy.

Table7. Analysis of Co-variance for students' poetry achievement scores by school location

\begin{tabular}{|l|l|l|l|l|l|}
\hline Sources of Variation & Sum of Squares & DF & Mean Square & F.cal & F.cv \\
\hline Covariate & 9962.301 & 1 & 9962.301 & 216.944 & \\
\hline Main Effect (location) & 703.523 & 1 & 703.523 & 15.320 & 3.89 \\
\hline Explained & 10880.071 & 8 & 1360.009 & 29.616 & \\
\hline Residual & 9276.052 & 202 & 45.921 & & \\
\hline Total & 20156.123 & 210 & 95.982 & & \\
\hline
\end{tabular}

As shown in Table 7, the calculated F.value (15.320) is greater than the critical F.value (3.89) at the alpha level of 0.05 . The researchers therefore reject the null hypothesis and conclude that there is a significant difference in the mean achievement scores of urban and rural secondary school students taught poetry using the song therapy

HO$_{4}$ : There is no significant difference in the mean achievement scores of male and female secondary school students taught poetry using the song therapy. 
Demystifying the Mystery That Surrounds the Comprehension of Poetry via Song Therapy: Our Experience

Table8. Analysis of Co-variance for students' poetry achievement scores by gender

\begin{tabular}{|l|l|l|l|l|l|}
\hline Sources of Variation & Sum of Squares & DF & Mean Square & F.cal & F.cv \\
\hline Covariate & 9962.301 & 1 & 9962.301 & 216.944 & \\
\hline Main Effects (gender) & 26.957 & 1 & 26.957 & 0.587 & 3.89 \\
\hline Explained & 10880.071 & 8 & 1360.009 & 29.616 & \\
\hline Residual & 9276.052 & 202 & 45.921 & & \\
\hline Total & 20156.123 & 210 & 95.982 & & \\
\hline
\end{tabular}

The result on Table 8 shows that the calculated F.value is 0.587 , while the critical F.value at the alpha level of 0.05 is 3.89. The calculated value in this case is less than the critical value at the given alpha level. Based on the decision rule, the researchers accept the null hypothesis and conclude that there is no significant difference in the mean achievement scores of male and female secondary school students taught poetry using the song therapy.

\section{SUMMARY OF FINDINGS}

The summary of findings includes the following:

- The students in the experimental groups had a higher mean achievement scores compared to students in the control group

- The mean achievement scores of students in the urban school was higher than the mean scores of the students in the rural secondary school

- The mean achievement scores of junior secondary school students(JSSII) students exposed to the treatment was greater compared to their senior secondary school secondary (SSS) counterparts

- The male students exposed to the treatment had a higher mean score than the female students, therefore the null hypothesis was rejected

- The mean achievement scores of junior and senior secondary students taught with the song therapy was significant

- The null hypothesis was rejected

- There is no significant difference in the mean achievement scores of male and female secondary school students taught poetry using the song therapy

\section{DisCuSSION}

The findings of this study are quite interesting. They confirm the experiences we had in our classrooms, when we used song therapy. The result shows that song therapy has no limit or boundary with respect to its application because all the students in the experimental classes (JSS and SSS II) showed a remarkable improvement in their comprehension of poetry. This is in agreement with the assertion of Davies (2000) that music has a way of connecting the function of the right and left hemisphere of the brain so that they work together towards making learning quick and easy. $\mathrm{He}$ further opines that music and song promote more complex thinking and assist in making connection for emotions, thinking and learning. This result also collaborated the assertions of Temple, Ogle, Crawford and Freppon (2008) that song helps students recognize and use rhymes; memorize words, phrases and sentences. This is true because song enhances repetitions and constant repetitions of words register such words in the memory of singers.

The findings also show that both students at the rural and urban areas enjoyed the use of song therapy. This was predicated on their commendable performances. The variable of 'location' was deliberately built into this study, because the researchers wanted to establish the fact that song therapy would also assist students in the rural areas as it does those in the urban area. However, there was an indication that students in the urban areas performed better than their contemporaries in the rural areas. The difference in the performance may be attributed to certain factors associated with students who attend schools in the rural areas: truancy, constant absenteeism from classes; poor attitude to reading, poor parental involvement in students' school work, poverty, and low linguistic ability. It was found that most of the students in the rural schools were not regular and consistent in their participation. This is believed to have affected their performances in the study and this therefore confirms the earlier assertion by Falioni (1993) that most students often trivialize the core essence of song therapy as a tool for learning. 
The improvement in the comprehension of poetry cuts across class levels, exposing the dynamism of using song therapy and the resultant effect. The performance of the junior secondary school students involved in the study was quite impressive compared to those in the senior secondary levels. This could be attributed to their age and class levels, because they are still fresh from primary school where they have been immersed in song and play as major tools for learning.

The performance of the male and female students provided another area of excitement in this study. It has generally been argued that boys performed better than girls in cognitive tasks but the use of songs provided an opportunity for girls to make their voices heard. This confirms Bintz (2010) submission that song, when used across curriculum helps all students' not just boys, learn across the curriculum. The findings of the study, therefore, is a positive indication of the need for language educators and reading teachers to provide diverse student - centered pedagogical strategies in their classrooms to meet students' needs, fortify their identified areas of strength and make them more independent and successful learners.

\section{Conclusion}

Teachers in this $21^{\text {st }}$ century should explore all the available options through which learning will be maximized. Davies(2000) avers that since Advertisers and filmmakers realize and utilize the power of music to evoke not only emotions, but also get our attentions and affect our choices and decisions in the products they promote, educators should explore the potentials in music, as advertisers of industries have done, and use it to advantage towards helping students to learn.

Songs are powerful pedagogical strategy that could be used to demystify the mysteries that often shroud the act of mastering poems. Most students who developed aversion for poetry as a genre of literature, attributed that to the abstract and technical nature of poetry. They feel that the poetic license of the poets gives them opportunity to use obsolete, queer and difficult words that often mar comprehension. However, our experiences in the classrooms were very productive, because our students changed their conception of poetry and developed interest and likeness to it as they do their favourite songs.

Good teaching makes an impact in the lives of students. Our experiences in the classrooms ignited the passion to have this study carried out in two different locations and the findings still confirmed our earlier claims that songs, when incorporated into a poetry lesson has the potentials to set the stage for learning by increasing students' interest, and activating their thinking and creativity. It was a worthwhile study, because all the students enjoyed every bit of the class interaction and a social learning environment was created in for maximum comprehension. We were able to build confidence in the learners though this strategy and their active involvement helped them to take control of their learning and become independent readers.

\section{REFERENCES}

Aloaili, A.S., 2005d. Arabic teachers' beliefs and practices in Riyadhcity in relation to constructivism. The Educational Journal 19 (76), 253-310.

Aloqaili,A.S (2012). The relationship between reading comprehension and critical thinking: A theoretical study. Journal of King Saud University-Languages Translation 24, 35-41

Bintz,W.P (2010). Singing across the curriculum. The Reading Teacher 63(8) 683-686. International Reading Association

Fakeye D. O., \& Temitayo, A. A (2013). Enhancing poetic literature instruction through stylistic and thematic approaches. Studies in Literature and Language, 6(2), 1-6.

French, J.N., Rhoder, C., 1992. Teaching Thinking Skills: Theory and Practice. Garland Publishing, Inc., New York.

Hijazi,D\&Al-natour,A (2012). The impact of using music on teaching English poetry in Jordanian universities. Journal of International Education Research 8(30 295-304.

Hoogland, C. (2011). Cognitive, affective and kinesthetic meaning making through the arts. Critical thinking: Teaching and testing in an era of educational accountability. London, ON: Althouse Press.

Lo, R. \& Fai Li,H.C, (1998). Songs enhance learner's involvement. English Teaching Forum 36, pp.3:8-11. 
Demystifying the Mystery That Surrounds the Comprehension of Poetry via Song Therapy: Our Experience

Lewis, J.,( 1991). Redefining critical reading for college critical thinking courses. Journal of Reading 34 (6), 420-423.

Maess, B \& Koelsch, S., (2001). Musical syntax is processed in Broca's Area: An MEG study. Nature Neuroscience, 4, pp.540-545.

Obiora,O (2009). Elements of literature: Analyses of recommended African and non-African poetry for WAeC and NECO (2011-2015).Lagos: Treasure Publishers Ltd.

Ofsted (2007). Poetry in schools: A survey of practice, 2006/2007. Retrieved on March 2012 from www.ofsted.gov.uk/publication

Okeowo,S (2004). Poetry for junior secondary schools .Onitsha: Africana first Publishers Plc.

Pike, M. (2000). Keen readers: Adolescents and pre-twentieth century poetry. Educational Review 52(1), 13-28.

Şahin, D., (2008).Teaching conditionals through songs in EFL preparatory classrooms. Yüksek Lisans Tezi, Selçuk Üniversitesi /Sosyal Bilimler Enstitüsü, Konya, p41

Sarıçoban, A. \&Metin, E. (2000),Songs, verse and games for teaching grammar. TESL Journal. Retrieved on the 18 of March 2015 from http://iteslj.org/Techniques/ Saricoban-Songs.htm

Simpson, P. (2004). Stylistic: a resource book for students. London: Routledge.

Temple,C.,Ogle,D.,Crawford,A., \& Freppon, P(2008). All children read: Teaching for literacy in today's diverse classrooms ( $2^{\text {nd }}$ ed).Boston: Allyn\& Bacon

West African Examinations Council. (2013). Chief Examiners' Report. Ikeja: Test Development Division

Zwicky, J. (2000). Wisdom and metaphor. Kentville, NS: Gaspereau Press. 